\title{
The Effect of Private Information and Monitoring on the Role of Accounting Quality in Investment Decisions
}

\author{
Anne Beatty, Scott Liao, and Joseph Weber \\ Version Post-print/accepted manuscript \\ Citation Beatty, Anne, W. Scott Liao, and Joseph Weber. "The Effect of Private \\ (published version) Information and Monitoring on the Role of Accounting Quality in \\ Investment Decisions*." Contemporary Accounting Research 27.1 \\ (2010): 17-47. Doi: 10.1111/j.1911-3846.2010.01000.x \\ Publisher's Statement This is the peer reviewed version of the following article: \\ Beatty, Anne, W. Scott Liao, and Joseph Weber. "The Effect of \\ Private Information and Monitoring on the Role of Accounting \\ Quality in Investment Decisions*." Contemporary Accounting \\ Research 27.1 (2010): 17-47, which has been published in final \\ form at Doi: 10.1111/j.1911-3846.2010.01000.x . This article may be \\ used for non-commercial purposes in accordance with Wiley \\ Terms and Conditions for Self-Archiving.
}

\section{How to cite TSpace items}

Always cite the published version, so the author(s) will receive recognition through services that track citation counts, e.g. Scopus. If you need to cite the page number of the author manuscript from TSpace because you cannot access the published version, then cite the TSpace version in addition to the published version using the permanent URI (handle) found on the record page.

This article was made openly accessible by $U$ of $T$ Faculty. Please tell us how this access benefits you. Your story matters. 
The Effect of Private Information and Monitoring on the Role of Accounting Quality in Investment Decisions

\author{
ANNE BEATTY \\ beatty.86@osu.edu, 614-292-541 \\ Fisher College of Business \\ The Ohio State University \\ 442 Fisher Hall \\ 2100 Neil Avenue \\ Columbus, $\mathrm{OH} 43210$
}

SCOTT LIAO

scott.liao@ rotman.utoronto.ca, 416-946-8599

Rotman School of Management

University of Toronto105 St. George Street

Toronto, ON M5S 3E6

JOSEPH WEBER

ipweber@mit.edu, 617-253-4310

Sloan School of Management

Massachusetts Institute of Technology

50 Memorial Drive, E52-325

Cambridge, MA 02142

June 30, 2009

*Corresponding author. Beatty thanks Deloitte \& Touche for financial support. The authors would like to thank Jennifer Altamuro, Ron Dye, Ben Lansford, Tom Lys, Waleed Muhana, Rick Johnston, Shail Pandit, Joe Piotroski, Shyam Sunder, Rick Young, Helen Zhang, and seminar participants at Stanford University, Northwestern University, and Ohio State University. 


\begin{abstract}
We investigate how private information and monitoring affect the role of accounting quality in reducing the investment-cash flow sensitivity. We argue that access to private information and direct restrictions on investments are likely to affect the extent to which accounting quality reduces financing constraints. Our results suggest that for financially constrained firms, banks' access to private information decreases the value of accounting quality. We further find that, for both financially constrained and unconstrained firms, covenants directly restricting capital expenditures also mitigate the importance of accounting quality. Our results suggest that when information asymmetry problems are likely to be the largest, accounting quality is most important. However, the importance of accounting quality is mitigated if outside capital suppliers have access to private information and is eliminated if they impose contractual restrictions on investment. We also provide evidence that banks' access to private information reduces the cash flow sensitivity of cash and mitigates the importance of accounting quality in reducing this sensitivity. This additional evidence suggests that our investment-cash flow sensitivity results are not driven by measurement error of the investment opportunity set.
\end{abstract}

Keywords Private information; Monitoring; Accounting Quality; Investment 


\section{Introduction}

Information asymmetry between managers and outside capital suppliers can affect how firms finance capital investments. A growing body of evidence indicates that better accounting quality can reduce information asymmetry costs and reduce financing constraints. Consistent with this possibility, Biddle and Hilary (2006) document that higher accounting quality reduces the sensitivity of firms' investment to their internally generated cash flows. Verdi (2006) and Biddle, Hillary, and Verdi (2009) find that accounting quality is positively correlated with investment for firms prone to under-invest and is negatively correlated with investment for firms prone to over-invest.

The importance of accounting quality on investment inefficiency may be mitigated when outside capital suppliers have private information or can directly monitor managers. By accessing private information and controlling managerial actions, outside capital suppliers can directly affect a firm's investments reducing the importance of accounting quality. Consistent with this idea, Biddle and Hilary (2006) compare the influence of accounting quality on investment efficiency across countries. They find that accounting quality influences investment efficiency in the U.S., but not in Japan. They suggest that one potential explanation for this cross-country difference is the mix of debt and equity in the capital structures of U.S. versus Japanese firms.

We extend this research by examining how different sources of financing affect the importance of accounting quality on firms' investment-cash flow sensitivity. Directly testing how different sources of financing influence the effect of accounting quality on the investment-cash flow sensitivity is challenging because a comparison of firms that recently obtained debt financing to those that did not could be affected by their ability to obtain financing. To alleviate this problem, we restrict our sample to firms that have all recently obtained debt financing and exploit the differences in access to private information and monitoring that exist across the public debt to private lending continuum as suggested by Diamond $1991 .^{1}$ We acknowledge that the sensitivity of investment to internal cash flows may be lower immediately after obtaining debt financing. However, this possibility would bias against rejecting our hypotheses.

Specifically, we identify a sample of 1,163 firms on the Securities Datacorp (SDC) database that have recently raised capital through the issuance of either public debt or syndicated bank debt. We restrict our sample to firms that have recently obtained debt financing to hold constant the firm characteristics 
associated with borrowing. However, within the sample of firms that have recently obtained debt financing, there are likely to be significant differences in the capital provider's access to private information and the constraints they place on managerial actions.

Diamond's (1991) theory implies that public debt holders have less access to private information and are thus less effective in monitoring borrowers than banks. Based on these arguments, we predict that accounting quality should have a larger influence on firms' investment-cash flow sensitivity for firms with public debt than for those with bank debt. Second, we expect that the effect of accounting quality on firms' investment policies will depend on whether lenders contractually restrict investment. We predict that when firms face contractual restrictions on investments, overinvestment problems are partially addressed, and accounting quality becomes less valuable and less likely to affect the investment-cash flow sensitivity.

To provide evidence on these hypotheses, we estimate a model of investments on internal cash flows separately for the sample of firms that only issue public debt and for the sample of firms that issue syndicated loans. In these regressions, we interact the cash flow variable with our measure of accounting quality to investigate whether accounting quality influences investment-cash flow sensitivities. For the bank sample, we further interact the product of the cash flow and accounting quality variables with the investment restrictions variables to examine whether capital expenditure covenants affect the investmentcash flow sensitivity. We use both ordinary least squares (OLS) and endogenous switching model estimation to address potential sample selection bias arising from the public versus bank debt financing choice. Our first-stage model of the determinants to enter the public versus private debt market follows Bharath, Sunder, and Sunder 2008. We estimate second-stage "regime" investment model regressions separately for firms that have public versus private debt. These regime regressions also control for endogeneity in the capital expenditure covenant choice using the fitted values from a first-stage regression model of the determinants of including an investment restriction in the debt contract.

Consistent with prior research, we find that investment is sensitive to internal cash flows and the investment-cash flow sensitivity is lower for firms with higher accounting quality. These results hold in both our OLS and endogenous switching model regressions. We also find that, for both estimation techniques, investment restrictions reduce the investment-cash flow sensitivity and reduce the importance of accounting quality. In this analysis using the overall sample, we do not find a relationship between the 
type of lender providing capital and the effect of accounting quality on the investment-cash flow sensitivity.

In a series of sensitivity analyses, we also consider the possibility that the investment-cash flow sensitivity captures information not only about financing constraints but also about firms' investment opportunities. To address this concern, we examine the effect of sources of financing on investment-cash flow sensitivities for financially constrained firms versus unconstrained firms.

To identify financially constrained firms we use an ex ante definition of financial constraint based on the Whited and Wu 2004 index. We expect that the investments of financially constrained firms, who have greater information asymmetry problems, will depend more on internally generated funds. Similarly, investment-cash flow sensitivities for financially constrained firms will depend more on the quality of accounting information, the existence of private information, and the use of contractual investment restrictions. Consistent with these conjectures, we find that for financially constrained firms, accounting quality is less important in reducing investment-cash flow sensitivities in the presence of private information. These results support the hypothesis that private information and accounting quality serve as substitutes. This result is also consistent with the notion that access to private information is more important when information asymmetry problems are likely to be high.

In a second sensitivity analysis, we adopt a balance sheet liquidity approach to address the concern that growth opportunities captured in our cash flow measures affect the association between cash flows and investments. Almeida, Campello, and Weisbach (2004) suggest that replacing investment with changes in cash holdings will reduce the influence of the investment opportunity set, as changes in cash balances should be uncorrelated with investment opportunities in the absence of financing constraints. Consistent with previous results, we find that accounting quality reduces the cash-cash flow sensitivity, but that lenders' access to private information decreases this effect.

Jointly, our results confirm the importance of accounting quality in mitigating the negative effects of information asymmetry on the investment-cash flow sensitivity. Our results are also consistent with Biddle and Hilary's 2006 argument that accounting quality should play a lower role when capital suppliers have alternative information problem mitigating mechanisms. However, they are inconsistent with accounting quality playing no role in improving investment efficiency in the debt market. ${ }^{2}$ 
Our paper also expands our understanding of the importance of accounting information by identifying the contexts in which the quality of the firm's accounting information is likely to be important. When information asymmetry problems are likely to be the largest, accounting quality is more important. However, in these settings, if outside capital suppliers impose contractual investment restrictions, or have access to private information, then accounting quality is less important. Furthermore, our finding that accounting quality reduces the sensitivity of balance sheet liquidity to cash flows and that the importance of accounting quality decreases in the face of bank debt suggests that our investment-cash flow sensitivity results are not merely due to cash flows capturing firms' investment opportunity sets.

Section 2 provides background for our study. We discuss our hypothesis development in Section 3. We describe our sample in Section 4 and our research design in Section 5. We discuss our empirical results in Section 6 and conclude in Section 7.

\section{Background}

\section{Related research}

Several recent papers examine the effect of accounting quality on firms' investments using a variety of approaches. Bushman, Piotroski, and Smith (2005) focus on firms' propensities to promptly withdraw capital from losing projects. They investigate whether firms located in countries with accounting regimes characterized by more timely accounting recognition of economic losses reduce capital investments more quickly when investment opportunities decline. They argue that their results support this hypothesis and that this effect is stronger in countries with more diffuse ownership.

Verdi (2006) is concerned not only with whether firms over-invest in losing projects, but also with whether they under-invest in positive net-present-value projects. His findings that higher accounting quality mitigates the overinvestment problem and that the effect is greater for firms with dispersed ownership are similar to those in Bushman et al. 2005. However, he states that he "cannot conclude that accounting quality is associated with lower underinvestment due to the reduction in information asymmetry between the firm and investors."

Biddle and Hilary (2006) examine how accounting quality affects firms' investment-cash flow sensitivity. They find that higher accounting quality is associated with lower investment-cash flow sensitivity in the U.S., but not in Japan. They argue that the difference in results across these two countries 
is driven by the fact that more capital in the U.S. is provided through arm's-length transactions with investors who do not have access to private information channels. They do not directly test this interpretation. Furthermore, as they acknowledge, it is not clear which attributes of the private debt markets drive their results. Their tests do not distinguish between lenders' ability to obtain private information versus their ability to monitor managers once capital is supplied. Thus, the existing research examining the effects of accounting quality on investments concludes that accounting quality improves investment efficiency, but the improvements are predominantly in firms with diffuse ownership where equity is likely to be the source of capital.

Given the results in Bharath et al. (2008), Francis, Schipper, and Vincent (2005), and Whittenberg-Moerman (2008) that firms with relatively higher accounting quality are rewarded with a reduction in the cost of debt, it is somewhat surprising that this lower cost of capital would not lead to improved investment efficiency. The central argument underlying these papers is that improved accounting quality allows lenders to reduce the costs associated with information asymmetry suggesting that accounting quality should increase investment efficiency even for firms that rely on debt financing. In this paper we attempt to reconcile these results by looking at the contexts in the U.S. debt markets in which accounting quality is likely to be the most important. We also attempt to distinguish between the effects of lenders' private information versus monitoring on the role accounting quality plays in reducing financing constraints and improving investment efficiency.

\section{Features of U.S. debt markets}

Diamond (1991) describes the U.S. debt market as a continuum of access to private information and monitoring. At one end of the spectrum are public debt holders who do not have direct access to private information and engage in very little monitoring. At the other end is private bank debt, which is characterized by lenders who have greater access to private information and by loans that contain numerous covenants. There is much theoretical banking literature that focuses on banks' ability to reduce information asymmetries. Empirical support for these theoretical models is provided by the findings in James 1987 that banks provide cheap "informed" funds as opposed to the costly "uninformed" funds provided by public

debt. Similarly, Krishnaswami, Spindt, and Subramaniam (1999) find that firms with a greater degree of information asymmetry rely more on bank debt. 
Previous research has also documented that covenant use differs for public versus bank debt. For example, Billet, King, and Mauer (2007) document covenant use for a sample of 7,567 public bonds issued between 1995 and 2003 with covenant data available on the FISD database. They find that less than 5 percent of these issues include capital expenditure restrictions, while Nini, Smith, and Sufi (2009) document that the incidence of these covenants in syndicated bank loans is much higher. ${ }^{3}$ They find capital expenditure restrictions in 32 percent of their sample of 3,720 deals with covenant data.

We exploit the difference in banks' access to private information relative to public debt holders to explore how private information affects the role that accounting quality plays in reducing investment-cash flow sensitivities. In addition, the prevalence of capital expenditure covenants in bank debt contracts allows us to further distinguish between the importance of banks' private information and their ability to monitor the borrower in mitigating information problems.

\section{Hypothesis development}

In the absence of information problems, investment decisions should not depend on internal cash flows. However, in the presence of information asymmetry between managers and outside capital suppliers, firms may face financing constraints causing them to rely on internally generated funds to finance their investments (Fazzari, Hubbard, and Peterson 1988 and 2000). Firms' dependence on internal cash flows will increase with the extent of information asymmetry between managers and capital providers.

Capital providers with greater access to private information (like banks) are likely to have superior information about firms compared to lenders that obtain their information from public sources (like public debt holders). ${ }^{4}$ Biddle and Hilary (2006) argue that banks' superior private information should serve as a substitute for accounting quality in determining the sensitivity of investment to internal cash flows. While this prediction is consistent with theoretical models such as Holthausen and Verrecchia 1998, recent empirical research suggests that rather than acting as substitutes, private information and public information may act as complements.

For example, Francis, Schipper, and Vincent (2002) find a positive association between the market reaction to analysts' reports and quarterly earnings announcement. Similarly, Chen, Cheng, and Lo (2006) argue that private and public information sources can complement one another if the public information contains complex data that is made more informative after additional explanation and interpretation. Given 
the conflicting predictions from the theoretical versus empirical work, we expect that access to private information and accounting quality could serve either as substitutes or as complements in determining the investment-cash-flow sensitivity. Our first hypothesis is:

HYPOTHESIS 1. The effect of accounting quality on the investment-cash flow sensitivity is mitigated for firms issuing bank debt relative to those issuing public debt if public and private information are substitutes and is enhanced if these two sources of information are complements.

In addition, banks often include explicit covenants in their debt agreements to limit managers' opportunistic investments. These covenants provide banks with an alternative mechanism to mitigate the problems associated with information asymmetry. Based on the assumption that capital expenditure covenants provide a substitute mechanism for addressing information problems, we expect that the importance of accounting quality in reducing the investment-cash flow sensitivity to be mitigated in the presence of these covenants. (The opposite prediction would hold if these covenants and accounting quality are complements rather than substitutes.) Our second hypothesis is:

HYPOTHESIS 2. The effect of higher quality accounting on the investment-cash flow sensitivity is mitigated by the existence of a capital expenditure covenant.

\section{Sample characteristics}

\section{Sample selection}

We test our hypotheses using a sample of firms listed on the SDC database that have issued public debt or entered into a syndicated loan. We include firm years in which these public or bank debts are outstanding. To deal with the selection bias of investment covenants in bank loans, we require that the SDC database have information on the size of the loan, the type of loan (revolver or term), and whether the bank

loan contains an investment covenant. ${ }^{5}$ We then merge this data with the COMPUSTAT database to obtain financial accounting information for the firm that entered into the loan or debenture. This data restriction resulted in a final sample of 1,163 firms (4,475 firm years) that had all of the data necessary to test our hypotheses.

Of the 4,475 firm years in our final sample we noted that 1,083 observations issued public debt, 3,392 observations issued bank debt (syndicated loans), and 1,026 observations issued both. Within the final bank debt sample, 1,124 observations are associated with the use of covenants that restrict investments 
representing 33 percent of the bank debt sample. These percentages are similar to those reported in Nini et al. 2009.

\section{Accounting quality proxy}

Given a lack of consensus about the best way to measure accounting quality we calculate four different measures of accounting quality and combine them to make one composite measure. ${ }^{6}$ All of our accounting quality measures are estimated on a firm-specific basis using 10 years of data, including the investment year. ${ }^{7}$ When estimating the regression we require at least eight years of observations.

Our first accounting quality measure, $\boldsymbol{A Q 1}$, is based on Dechow and Dichev 2002. This measure captures the extent to which accruals map into cash flows. For each firm in the sample we run a time-series regression of total current accruals on cash flows from operations measured concurrently and with a one period lead and one period lag. The variable $\boldsymbol{A Q 1}$ is measured as the quintile ranking of Adjusted Rsquared from these regressions (this measure is consistent with the measure used in Biddle and Hilary 2006). Following Wysocki (2005), our second measure of earnings quality is a measure of earnings persistence. For each sample firm, we run a time-series regression of one period ahead earnings on current earnings. The variable $\boldsymbol{A Q 2}$ is measured as the quintile ranking of coefficients on current earnings from these regressions.

Our third measure of earnings quality, $\mathbf{A Q 3}$, is measured as the quintile ranking of Adjusted Rsquared from our earnings persistence model, and is designed to measure earnings predictability. Our fourth measure, $\boldsymbol{A Q 4}$, captures cash flow predictability. It is measured as the quintile ranking of Adjusted $\mathrm{R}$-squared from a regression of one-year-ahead cash flows on current earnings. We then combine these four measures by taking the average of the ranks of each of our four individual measures to create our composite measure, $\boldsymbol{A Q}$.

\section{Research design}

\section{Investment model}

We test our hypotheses about the effects of accounting quality, investment restrictions, and banks' private information on the investment-cash flow sensitivity by estimating the following investment model: ${ }^{8}$

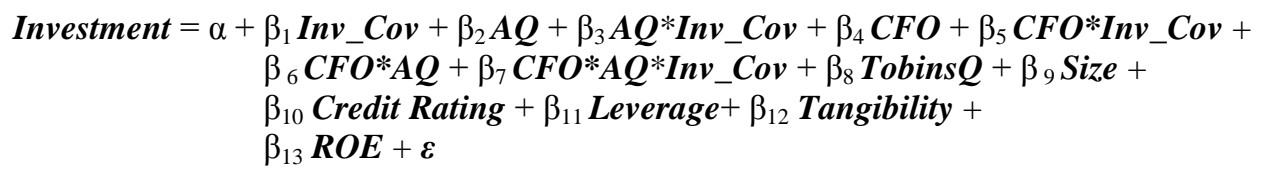




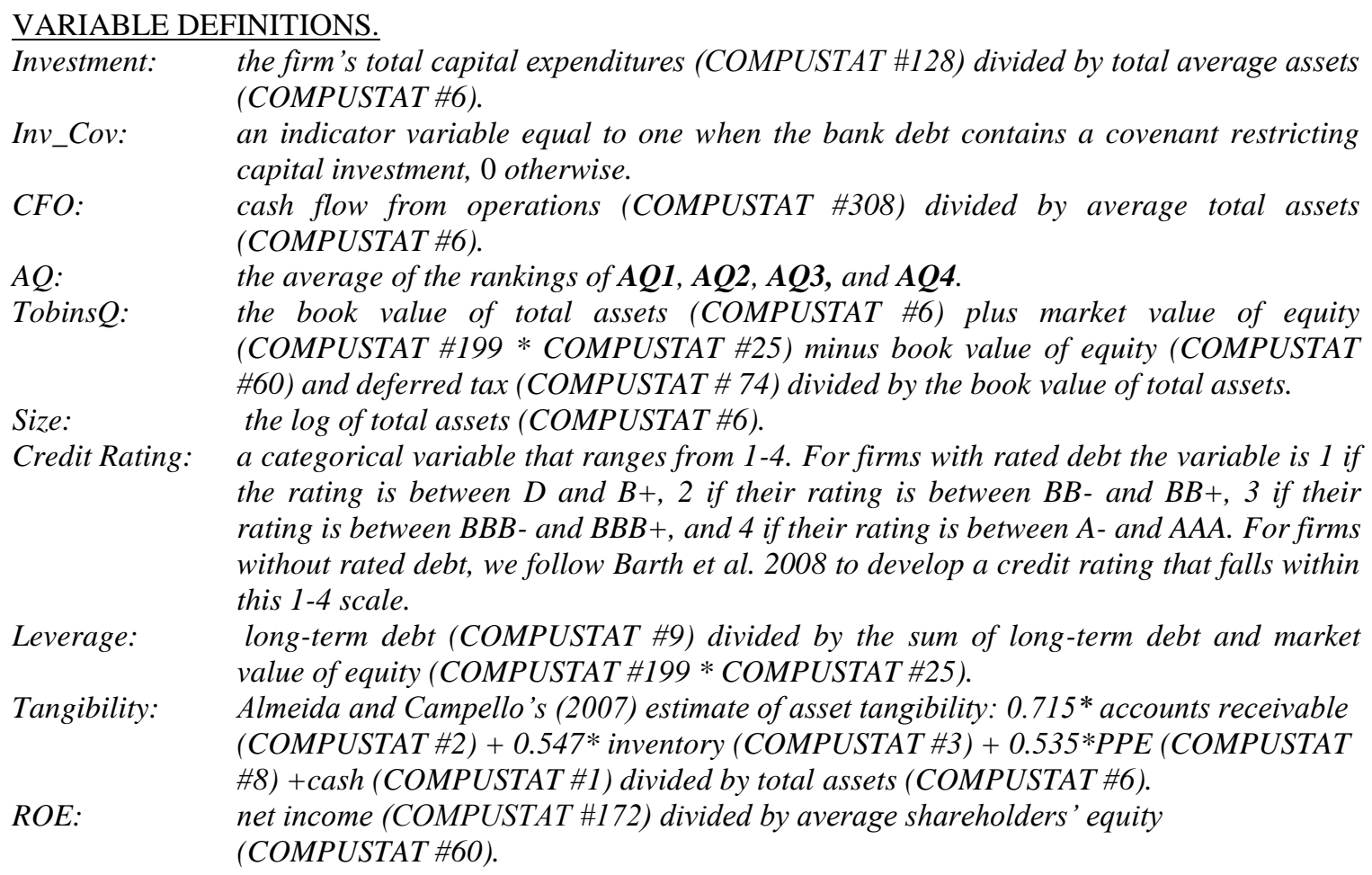

Credit Rating: a categorical variable that ranges from 1-4. For firms with rated debt the variable is 1 if the rating is between $D$ and $B+, 2$ if their rating is between $B B$ - and $B B+, 3$ if their rating is between $B B B$ - and $B B B+$, and 4 if their rating is between $A-$ and $A A A$. For firms without rated debt, we follow Barth et al. 2008 to develop a credit rating that falls within this 1-4 scale.

Leverage: long-term debt (COMPUSTAT \#9) divided by the sum of long-term debt and market value of equity (COMPUSTAT \#199* COMPUSTAT \#25).

Tangibility: $\quad$ Almeida and Campello's (2007) estimate of asset tangibility: $0.715^{*}$ accounts receivable $($ COMPUSTAT \#2) $+0.547 *$ inventory $($ COMPUSTAT \# 3$)+0.535 * P P E($ COMPUSTAT \#8) +cash (COMPUSTAT \#1) divided by total assets (COMPUSTAT \#6).

ROE: $\quad$ net income (COMPUSTAT \#172) divided by average shareholders' equity (COMPUSTAT \#60).

Consistent with existing research, we measure the extent of the firm's investing activities, Investment, as the total capital expenditures of the firm. In an untabulated sensitivity analysis we also include expenditures on research and development in our measurement of investment and find similar results to those reported in the paper. ${ }^{9}$ We measure cash flows, $\boldsymbol{C F O}$, as the cash flows from operations since it excludes accruals that may be correlated with investments. ${ }^{10}$

If firms' investments are sensitive to their internal cash flows then we would expect a positive coefficient on the $\boldsymbol{C F O}$ variable. Higher accounting quality should reduce the information problems that lead to the investment-cash flow sensitivity, so we expect the coefficient on $\boldsymbol{C F} \boldsymbol{O}^{*} \boldsymbol{A} \boldsymbol{Q}$ to be negative. We also include control variables for other factors that are likely to affect the firm's investment choices. ${ }^{11}$ Consistent with previous research, we control for the firm's growth options in place by including Tobins $Q$, which we expect to be positively correlated with investment. In addition, we control for Size, Credit Rating, and Leverage. Smaller firms, firms with lower credit ratings, and more levered firms are expected to have fewer investments. Finally, we also include controls for the tangibility of the firm's assets, 
Tangibility, and firm performance, $\boldsymbol{R O E}$, but we do not make explicit predictions on the effect of these variables on investment.

Our analysis is conducted at the firm-year level using all firm years with available data between the debt issuance and maturity dates. Thus, each year after the firm has entered into the loan, we measure investment and the corresponding independent variables until the loan matures. For those loans that occur towards the end of our sample period, we artificially set the debt "maturity" to 2005 , since financial data beyond 2005 is not available. We include firm fixed effects and year fixed effects in our regressions.

To test Hypothesis 1, we compare the coefficients on $\boldsymbol{C F O} \boldsymbol{A} \boldsymbol{Q}$ across public versus bank debt samples. We hypothesize that the coefficient on $\boldsymbol{C F O} * \boldsymbol{A Q}$ should be lower in the bank debt sample if private information and accounting information serve as substitutes and should be higher if these sources of information are complements. ${ }^{12}$ To test Hypothesis 2, we include a measure of the use of investment covenant restrictions, Inv_Cov, in the regression..$^{13}$ The existence of an investment covenant restriction is expected to reduce the importance of information asymmetries and is therefore expected to reduce the benefits of higher accounting quality, thus the coefficient on $\boldsymbol{C F O} * \boldsymbol{A} \boldsymbol{Q} * \boldsymbol{I n} \boldsymbol{n} \boldsymbol{C}_{-} \boldsymbol{C o v}$ is expected to be positive. $^{14}$

Since the choice of issuing bank debt versus public debt is likely to cause a self-selection bias in OLS regressions, we estimate an endogenous switching model that controls for the selection problem associated with the debt-financing source. Similarly, the choice of using debt covenants to restrict investments is also likely to be endogenously determined. To address this concern, we estimate a first-stage model of the determinants of the decision to include an investment restriction in the debt contract and include the fitted value from that model in our endogenous switching model.

\section{Endogenous switching model of public versus bank debt choice}

To measure private information's effect on the relationship between accounting quality and investment-cash flow sensitivities, we compare sub-samples of firms with public versus bank debt. The public debt subsample includes firm years in which no syndicated bank loan was currently or previously issued. The bank debt sub-sample refers to firm years with at least one syndicated bank loan outstanding.

To control for the endogeneity of the choice of bank debt and public debt, we follow Bharath et al. 2008 estimating an endogenous switching model proposed by Lee 1978. The endogenous switching model 
has a first-stage selection equation for the choice between public and bank debt and two second-stage "regime" equations modeling the determinants of investment (one for the bank debt sub-sample and one for public debt sub-sample). Similar to Bharath et al. (2008), this approach allows us to control for the selfselection of debt choice and compare the effects of accounting quality on CFO across the two regimes.

The first-stage model of debt choice includes variables from Denis and Mihov 2003, Krishnaswami et al. 1999, and Bharath et al. 2008. Specifically, we argue that debt choice depends on the firm's accounting quality $(\boldsymbol{A Q})$, where firms with better quality are more likely to choose public debt. The choice will also depend on the firm's profitability, where more profitable firms will access public debt.

Based on this argument we include $\boldsymbol{C F} \boldsymbol{O}$ and $\boldsymbol{R} \boldsymbol{O E}$ in the regression. The choice is also likely to depend on size, growth options, credit quality, and leverage so we include our Size, TobinsQ, Credit Rating, and Leverage variables. Finally the choice will also depend on the tangibility of the firm's assets, so we include Tangibility in the regression.

Similar to Bharath et al. (2008), we include Rated to control for the access to public debt market as an identification instrument. In addition, considering that financial constraints play a role in deciding financing sources, we follow Whited and Wu 2004 and include DivPos as a second instrumental variable. ${ }^{15}$ Thus the first-stage probit model is as follows:

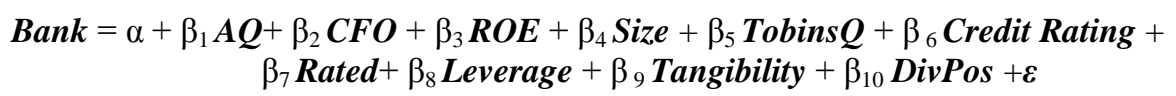

\section{VARIABLE DEFINITIONS.}

Bank: a dichotomous variable that is set equal to one if the firm issues bank debt during our sample period, and 0 otherwise.

AQ: $\quad$ the average of the rankings of $A Q 1, A Q 2, A Q 3$, and $A Q 4$.

CFO: $\quad$ cash flow from operations (COMPUSTAT \#308) divided by average total assets (COMPUSTAT \#6).

ROE: $\quad$ net income (COMPUSTAT \#172) divided by average shareholders' equity (COMPUSTAT \#60).

Tobins: $\quad$ the book value of total assets (COMPUSTAT \#6) plus market value of equity (COMPUSTAT \#199* COMPUSTAT \#25) minus book value of equity (COMPUSTAT \#60) and deferred tax (COMPUSTAT \#74) divided by the book value of total assets.

Size: $\quad$ the log of total assets (COMPUSTAT \#6).

Credit Rating: a categorical variable that ranges from 1-4. For firms with rated debt the variable is 1 if the rating is between $D$ and $B+, 2$ if their rating is between $B B$-and $B B+, 3$ if their rating is between $B B B$ - and $B B B+$, and 4 if their rating is between $A$-and $A A A$. For firms without rated debt, we follow Barth et al. 2008 to develop a credit rating that falls within this 1-4 scale.

Rated: $\quad$ an indicator variable that equals one for firms rated by the $S \& P$.

Leverage: $\quad$ long-term debt (COMPUSTAT \#9) divided by the sum of long-term debt and market value of equity (COMPUSTAT \#199* COMPUSTAT \#25). 
Tangibility: $\quad$ Almeida and Campello's (2007) estimate of asset tangibility: $0.715^{*}$ accounts receivable (COMPUSTAT \#2) + 0.547* inventory (COMPUSTAT \#3) + 0.535*PPE (COMPUSTAT \#8) +cash (COMPUSTAT \#1) divided by total assets (COMPUSTAT \#6).

DivPos: an indicator that takes the value of one if the firm pays cash dividends (COMPUSTAT \#21).

The second-stage regressions are the regime regressions described by equation 1 . There are two modifications that we make to this regression. First, as opposed to estimating the "regime" regression separately using OLS in each sample, we use full information maximum likelihood and estimate the three regressions simultaneously. Second, as opposed to including the indicator variable Inv_Cov in the regression, we allow for the decision to include an investment restriction to be endogenously determined with the investment choice. This requires us to develop a prediction model of the decision to include an investment restriction in the debt contract, and to derive a fitted value from this model using two-stage least squares.

\section{Model of investment restriction covenant use}

Our first-stage model of the decision to include investment restriction covenants includes variables drawn from Nini et al. 2009 and from our model of public versus bank debt choice. We also include $\boldsymbol{A Q}$ in our model to allow for the possibility that accounting quality and investment covenants provide alternative methods of addressing the agency problems of debt. Consistent with the findings of Nini et al. (2009) that the use of this covenant is less prevalent for firms that are larger and that have higher credit ratings, we include Size, Credit Rating, and Rated in our model. ${ }^{16}$ They also find mixed evidence that the use of this covenant is less prevalent for firms with higher market to book ratios and with lower debt relative to cash flows. ${ }^{17}$ We include Tobins $Q$, Leverage, and $\boldsymbol{C F O}$ in our model to capture these constructs.

We also allow the decision to include an investment restriction in the firm's debt contract to depend on the firm's profitability, tangibility, and dividend payments. Therefore, we include $\boldsymbol{R O E}$, Tangibility, and DivPos in our model. Finally, we allow the investment covenant decision to depend on characteristics of the contract as instrumental variables, like the size of the loan and the type of loan. Specifically, we include Debt Amount, calculated as the natural $\log$ of the amount of bank debt, and Revolver, which is an indicator variable coded to be one if the loan is revolving; otherwise, it is set to be 0 . Since the decision to include an investment restriction in the debt contract is made at the inception of the debt contract, all variables are measured prior to the bank debt issuance. 
We construct a predicted Inv_Cov variable that equals one if the predicted probability of using Inv_Cov based on estimates from the following first-stage probit model is greater than 50 percent and that equals 0 otherwise.

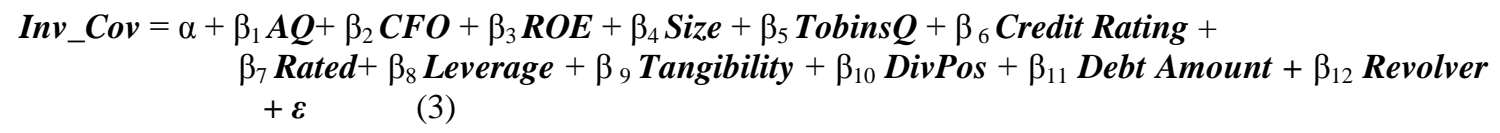

\section{VARIABLE DEFINITIONS.}

Inv_Cov: an indicator variable equal to one when the bank debt contains a covenant restricting capital investment, 0 otherwise.

$A Q: \quad \quad \quad \quad$ the average of the rankings of $A Q 1, A Q 2, A Q 3$, and $A Q 4$.

CFO: $\quad$ cash flow from operations (COMPUSTAT \#308) divided by average total assets (COMPUSTAT \#6).

ROE: $\quad$ net income (COMPUSTAT \#172) divided by average shareholders' equity (COMPUSTAT \#60).

TobinsQ: $\quad$ the book value of total assets (COMPUSTAT \#6) plus market value of equity (COMPUSTAT \#199 * COMPUSTAT \#25) minus book value of equity (COMPUSTAT \#60) and deferred tax (COMPUSTAT \#74) divided by the book value of total assets.

Size: $\quad$ the log of total assets (COMPUSTAT \#6).

Credit Rating: a categorical variable that ranges from 1-4. For firms with rated debt the variable is 1 if the rating is between $D$ and $B+, 2$ if their rating is between $B B$ - and $B B+, 3$ if their rating is between $B B B$ - and $B B B+$, and 4 if their rating is between $A$ - and $A A A$. For firms without rated debt, we follow Barth et al. 2008 to develop a credit rating that falls within this 1-4 scale.

Rated: $\quad$ an indicator variable that equals one for firms rated by the $S \& P$.

Leverage: long-term debt (COMPUSTAT \#9) divided by the sum of long-term debt and market value of equity (COMPUSTAT \#199* COMPUSTAT \#25).

Tangibility: $\quad$ Almeida and Campello's (2007) estimate of asset tangibility: $0.715 *$ accounts receivable (COMPUSTAT \#2) + 0.547* inventory (COMPUSTAT \#3) + 0.535*PPE (COMPUSTAT \#8) + cash (COMPUSTAT \#1) divided by total assets (COMPUSTAT \#6).

DivPos: $\quad$ An indicator that takes the value of one if the firm pays cash dividends (COMPUSTAT \#21).

Debt Amount: $\quad$ the natural log of the amount of the bank debt.

Revolver: an indicator variable that equals one if the loan is a revolver.

Financing constraints index

While there is considerable debate about whether the investment-cash flow sensitivity actually captures a lack of access to external financing (Fazzari et al. 2000; Kaplan and Zingales 2000), there is some consensus that this measure behaves differently between financially constrained and unconstrained firms. Whited and $\mathrm{Wu}(2004)$ state that financially constrained firms act as if they have high discount rates, which is likely to cause these firms to rely on internal cash flows. If the existence of financing restrictions suggests an increase in the importance of information asymmetry problems then we would expect accounting quality, access to private information, and investment restrictions to have a greater influence on investment-cash flow sensitivity for financially constrained firms. 
To provide evidence on whether financial constraints affect the relationship between investment and internal cash flows, we partition the sample into firms that are more versus less likely to have financial constraints using the index developed by Whited and Wu 2004. They suggest that the extent of the firm's financing constraints is a function of the firm's leverage, sales growth, cash flow, and dividend policy. Their index is calculated as:

$\boldsymbol{F C I n d e x}=-0.062 * \boldsymbol{T L T D}+0.01 *$ DivPos $+0.067 * \boldsymbol{S G}+0.06 *$ Size $-0.043 * \boldsymbol{I S G}+0.053 * \boldsymbol{C F}$

\section{VARIABLE DEFINITIONS.}

TLTD: $\quad$ the firm's long-term debt (COMPUSTAT \#9) divided by total assets (COMPUSTAT \#6).

DivPos: $\quad$ an indicator that takes the value of one if the firm pays cash dividends (COMPUSTAT \#21).

SG: $\quad$ change in sales divided by lagged sales (COMPUSTAT \#12).

Size: $\quad$ the natural log of total assets (COMPUSTAT \#6).

ISG: $\quad$ the firm's three-digit industry sales growth.

CF: $\quad$ the ratio of cash flow, measured by earnings before extraordinary (COMPUSTAT \#123) plus depreciation (COMPUSTAT \#14), to total assets.

For each firm in our sample, we calculate this index, and then partition the sample into two groups at the median of the distribution. We then rerun our analyses on the firms that are financially constrained. We omit reporting the results on the unconstrained sample, for parsimony.

\section{Cash model}

In order to address the concern that growth opportunities implied in our cash flow measure might drive the result, we also consider a different approach to capture financing constraints. Almeida, Campello, and Weisbach (2004) suggest that estimating the effect of cash flows on balance sheet liquidity provides an alternative method of detecting financing constraints. They argue that the sensitivity of changes in the cash balance to cash flows from operations is less subject to concerns about cash flows measuring investment opportunities since, in the absence of financing constraints, the change in the cash balance should not be correlated with investment opportunities. We follow Almeida et al. (2004) and estimate the following cash model using annual data for each firm year after the debt issuance until the debt matures with sufficient available data:

\section{$\Delta$ Cash $=\alpha+\beta_{1} A Q+\beta_{2} C F O+\beta_{3} C F O * A Q+\beta_{4}$ Tobins $Q+\beta_{5}$ Size + $\beta_{6}$ Credit Rating $+\beta_{7}$ Leverage $+\beta_{8}$ Tangibility $+\beta_{9}$ ROE $+\varepsilon$,}

where $\boldsymbol{\Delta C a s h}$ is the change in cash reported in the balance sheet (COMPUSTAT \#1) scaled by lagged total asset (COMPUSTAT \#6) and all other variables are as defined above. 


\section{Results}

\section{Descriptive statistics}

Table 1 provides descriptive statistics for our sample. Columns 2 and 3 of Table 1 provide means for our test and control variables for sample firms partitioned by whether they have bank debt. When we compare firms that have only public debt to those that have bank debt, we find no significant difference in our accounting quality measure. Similarly, when we compare the extent of investment, the amount of cash flows from operations, and the change in cash, we find that firms that have only public debt appear no different than firms that have bank debt. We also note that firms with bank debt are smaller, have lower credit rating, and more tangible assets. Firms with bank debt are also less profitable, more financially constrained, and less likely to pay dividends.

Columns 4 and 5 of Table 1 provide means for our test and control variables for sample firms partitioned by whether they have bank debt that contains an investment restriction versus bank debt that does not have an investment restriction. Again, we do not find significant difference in accounting quality measures between these two groups. We also find that firms that have investment restrictions in their debt contracts spend less money on capital expenditures after they enter into the debt contract. They also have lower cash flow from operations. However, we find no difference in the change in cash across these two groups of firms. In addition, we find that firms with investment restrictions have fewer growth options, smaller size, lower credit rating, higher leverage, lower tangibility, and lower profitability. Firms with investment covenants are also less likely to be rated, more financially constrained, and less likely to pay dividends.

\section{Results from first-stage selection models}

Table 2 reports the results of our first-stage "selection" models. The first two columns report the results of the model of the determinants to use bank debt or public debt as a source of financing. The second two columns of data report the results of our model of the determinants of the decision to include an investment restriction in the firm's debt contract.

Focusing on the determinants of the source of financing, we find that firms are more likely to use bank debt when they are smaller, have lower credit quality, less tangible assets, and are not paying dividends. More importantly, both instrumental variables (Rated and DivPos) have significant loadings. To test 
whether these two variables are effective identification variables, we include these two variables in an aggregate investment model. ${ }^{18}$ The results seem to suggest that these two instruments are effective identifiers, that is, these two variables do not have significant correlations with investments.

Similar to the examination of the determinants of the source of financing, we also find that profitability (as measured by $\boldsymbol{C F O}$ ), size, credit quality, asset tangibility, and dividend paying position are associated with the decision to include investment covenant restrictions in the firm's debt contracts. We also find that one of our exogenous variables, Revolver, is associated with the decision, where revolving loans are less likely to have investment restrictions. Since revolving loans can be drawn down and repaid many times over the life of the contract, it is not surprising that they are less likely to have investment restrictions.

\section{Results from OLS and endogenous switching estimation of the investment model}

Table 3 reports the results of our analysis of our investment model. The first two columns report the results from our OLS regressions, which do not account for the endogeneity of the financing or the investment covenant choices. The second two columns report the results of our endogenous switching model.

Focusing first on the OLS results, we find that $\boldsymbol{C F O}$ is positively correlated with investment for the firms with public debt and the firms with bank debt, suggesting that financial constraints affect investment decisions. For both sets of firms we also find that the effect is mitigated by the quality of the firm's financial accounting information. This is consistent with both Biddle and Hilary (2006) and Verdi (2006): Firms with better accounting quality have fewer information asymmetries and are less likely to face financing constraints.

We also find that investment restrictions appear to both reduce the association between $\boldsymbol{C F O}$ and investment and eliminate the effect of accounting quality on the relationship between cash flows and investment. This suggests that monitoring mechanisms, like covenants that restrict investment, can alleviate financing constraints and eliminate the importance of accounting information in the financing decision. (Note that in this table, we can't compare the effects of investment restrictions between the two samples as we assume that public debt does not contain such covenants (see endnote 3 and 13)). 
The endogenous switching tests yield results that are very similar to the OLS models. That is, we find that $\boldsymbol{C F O}$ is associated with investment, and that good accounting quality reduces this association. We further find that investment restriction covenants appear to diminish the association and investment covenants also dampen the effects of accounting quality. While we only report the comparisons of key coefficients across regimes using the endogenous switching model, the comparisons for the OLS models are similar. The results of these tests are reported at the bottom of the table. We find no difference in the coefficients on $\boldsymbol{C F O} * \boldsymbol{A} \boldsymbol{Q}$ across the two regimes, suggesting that banks' private information does not diminish the importance of accounting quality in the investment decision. In unreported tables where we do not interact $\boldsymbol{A Q}$ and $\boldsymbol{C F O} * \boldsymbol{A Q}$ with $\mathbf{I n v} \boldsymbol{C} \boldsymbol{C} \boldsymbol{v}$, the coefficient on $\boldsymbol{C F O} * \boldsymbol{A} \boldsymbol{Q}$ is lower (albeit weakly significant ( $\mathrm{p}$-value=0.12)) in the bank debt sample than the public debt sample.

Comparing the results from the OLS models to the endogenous switching model, we see that our attempts at controlling for the endogeneity of financing choice do not have a large impact on the coefficients in the regressions. This finding is similar to Bharath et al. 2008 as the statistical significance is similar in both sets of regressions. This suggests that either our attempts at addressing endogeneity are not adequate or that endogeneity is not a significant problem in this setting. Since we cannot differentiate between these two alternatives, the reader should be cautious when interpreting our results.

\section{Results from analysis on firms likely to be constrained}

Table 4 reports the results of our investment model for the financially constrained sub-samples. Recall that firms that are financially constrained are more likely to rely on cash flows from operations to fund their investment, and thus accounting quality, investment restrictions, and private monitoring are more likely to have an effect on investment decisions. Similar to Table 3, the first two columns report the results from our OLS regressions, while the second two columns report the results of our endogenous switching model.

In both the OLS and the endogenous switching models, we find that $\boldsymbol{C F O}$ is associated with investment, that investment restriction covenants diminish this association, and that investment covenants eliminate the effects of accounting quality on the investment-cash flow sensitivity.

Our test of the equivalence of the coefficient on the $\boldsymbol{C F O} * \boldsymbol{A} \boldsymbol{Q}$ variable across the two regimes in the endogenous switching model indicates that banks' access to private information is important and 
reduces the effect of accounting quality on the investment-cash flow sensitivity for firms likely to have the most severe information problems. In contrast to the results for the entire sample, which suggest that access to private information does not affect the importance of accounting quality on the investment-cash flow sensitivity, this result suggests that private information and public financial reporting serve as substitutes in mitigating information problems for firms facing financing constraints. Again, while not tabulated, this result holds in the OLS model and models where we do not interact $\boldsymbol{C F O}$ and $\boldsymbol{C F O} * \boldsymbol{A} \boldsymbol{Q}$ with $\boldsymbol{I n v} \boldsymbol{C o v}$.

\section{Results from cash-on-cash flow models}

We report the results of estimating our balance sheet liquidity model in Table 5. The results look very similar to those from the investment model for constrained firms. Specifically, we find that association between cash flows and the cash balance is higher for firms that issue public debt than for firms that use private bank loans. The results also indicate that the association between cash flows and cash balances is decreasing in accounting quality for firms that issue public debt (but not for firms issuing bank debt). The results from the endogenous switching model indicate that the effect of accounting quality is lower for firms using private bank loans than for firms issuing public debt.

Taken together, the results in Tables 4 and 5 suggest that our investment-cash flow sensitivity results are not merely an artifact of a potential correlation between cash from operations and the investment opportunity set. Specifically, this interpretation is supported by our findings that the coefficients on the interactions of cash from operations with accounting quality and the bank debt indicator are only significant for the financially constrained firms and that they are also significant in explaining cash retention.

\section{Sensitivity analyses}

To further ensure that our results are not just an artifact of our research design, we conduct a number of additional sensitivity analyses. First, our analysis focuses on firm years after the initiation of a debt contract. We make this research design choice because it allows us to measure the lender's access to private information and whether there are contractual restrictions on investment after the capital is provided. However, a drawback of this research design is that the firms in our sample have recently accessed the capital markets. In an untabulated sensitivity analysis, we rerun our tests in the period prior to the firm raising capital. We continue to find that accounting quality reduces the sensitivity of investment to internal cash flows. Our variable measuring whether there is a contractual restriction on investment is 
insignificant in the pre-loan period. This result suggests that it is the actual restriction on investment (rather than a sample-selection bias) that reduces the sensitivity of cash flows to investment. Similarly, the interaction between accounting quality and our variable measuring the access to private information is insignificant, suggesting that it is the actual access to private information (rather than self-selection) that reduces the importance of accounting quality.

Second, we partition our sample using different financial constraint metrics. Following prior studies, we use firm size, whether the firm is rated, and whether the firm has investment grade debt as financial constraint proxies. Unreported results show that all partitions generate similar results to those partitioned by the Whited and Wu 2004 index.

Third, we redid the analysis year-by-year. We note that as we move out over the life of the contract, the results generally get stronger. This result is not surprising, since firms are less likely to rely on internal cash flows for investment in the first year or two after raising external capital.

Fourth, following Alti's (2003) suggestion, we use lagged cash flow instead of current cash flow to investigate investment-cash flow sensitivities. This approach potentially mitigates the concern that current cash flow contains growth opportunities information. We redid all analyses with this instrumental variable, and the results are qualitatively similar.

Finally, our research design assumes that private lenders do not monitor the public debt sample. We coded firms that issued public and syndicated bank debt (as per the SDC database) as being in the bank debt sample. However, some firms may have issued private placements or bank debt, which is not captured on the SDC database. To attempt to address this issue, we identified the COMPUSTAT data items where new debt issues are likely to be located, and eliminated all firms that had a change in these items during the post-issuance period. ${ }^{19}$ While this reduced our public debt sample by 36 percent, we find that the results of this analysis are qualitatively similar to those reported in the paper.

\section{Conclusions}

Previous research shows that higher accounting quality reduces the sensitivity of firms' investments to internal cash flows. Biddle and Hilary (2006) find that this relation exists in the U.S., but not in Japan and they conclude that accounting quality should play a lower role when capital suppliers have alternative information sources. 
Our paper extends this research, examining the factors within the debt market that enhance or diminish the importance of accounting information in reducing financing constraints. We examine a sample of U.S. firms that have recently raised debt financing and investigate the role of private information and monitoring on the sensitivity of investment to internal cash flows. We find that improved accounting quality decreases investment-cash flow sensitivities for firms that issue either public debt or bank debt. We also find that investment restrictions eliminate the influence of accounting quality on the investment-cash flow sensitivity. In addition, we find that for firms with high financial constraints, lenders' private information also mitigates the role of accounting quality in reducing the investment-cash flow sensitivity.

We find that our results hold even when we allow for the possibility that cash flows not only capture firms' reliance on internally generated funds, but may also capture information about firms' investment opportunities. Specifically we find that for firms facing financing constraints, where information asymmetry problems are likely to be the largest, accounting quality is most important. Furthermore, we find that our results hold when we examine the cash flow sensitivity of balance sheet liquidity.

Our paper extends the financial economics literature that discusses the relation between financial constraints and investment decisions. We find that the source of financing affects investment decisions. Our paper further distinguishes the informational and monitoring roles played by banks in reducing financing constraints. These results are interesting because they help us understand the implications of different forms of debt financing in investment decisions and their interactions with accounting information. 


\section{Endnotes}

1. An alternative would be to investigate the role of relationship banking on the sensitivity of investment to cash flows. The SDC loan database has mostly syndicated loans. The lack of a significant number of "relationship" loans limits our ability to explore this possibility.

2. The inconsistency between our findings and those of Biddle and Hillary's (2006) results for Japan might arise because of differences in the type of debt across the two papers. Our debt sample is comprised of public debt and syndicated loans whereas their Japanese firms rely more heavily on relationship banking, where private information is likely to be the most readily available.

3. Their public debt sample includes a variety of different covenants primarily related to restrictions on mergers and restrictions and on issuances of additional debt. Similarly, Chava, Kumar, and Warga (2007) report that 92.9 percent of their public debt sample has restrictions on mergers and acquisitions, 21.7 percent have covenants that indirectly constrain investments, but only 1.4 percent have direct investment restrictions.

4. Yu (2007) provides evidence that banks have superior information compared to other sophisticated investors such as analysts.

5. If covenant information was not disclosed in the SDC database, the observation was not included in our sample. Loans that are missing covenant information in the database often have covenants.

6. In an untabulated sensitivity analysis, we also ran each measure separately in our main tests. The results are similar to those we report. We omit them for parsimony.

7. The results are similar if the accounting quality measures exclude the investment year.

8. Since our investment model includes two- and three-way interactions we examine the variance inflation factors for the coefficients estimated in these models. The VIFs, which range from a low of 1.09 to a high of 2.65, are well below the level that would suggest that multicollinearity is causing a problem.

9. We considered including mergers and acquisitions in our investment measure, but bank debt typically has covenants restricting firms from engaging in this activity. These covenants are distinct from the investment restriction covenant that is our focus. Analyzing this alternative form of investment is beyond our scope.

10. We use CFO rather than CF (earnings plus depreciation) because CFO is more theoretically correct. As Bushman, Smith, and Zhang (2007) point out, CF contains accruals, so regressing investment on CF is like regressing investment on investment. Although Bushman et al. (2007) do not find that the correlation between CFO and investment varies with ex ante financial constraint variables, Biddle and Hilary (2006) find that the correlation does depend on financial constraints. The discrepancy might be driven by sample differences.

11. In our tabulated results the control variables are all lagged values. Using the current value doesn't qualitatively change the results.

12. Using the current model (Equation 1) to test the equality of coefficients on $\boldsymbol{C F O} * \boldsymbol{A} \boldsymbol{Q}$ only compares public debt and bank debt that does not contain an investment covenant.

13. Although the SDC database does not provide information on covenants for public debt, we assume that none of the public debt contracts in our sample have direct investment restrictions based on the low rate (i.e., 1.4 percent) of these covenants in public debt reported by Chava et al. 2007.

14. For completeness, we will also discuss the results of models where we do not include $\mathbf{I n v} \boldsymbol{C} \boldsymbol{C o v}$ and its interactions with other variables. 
15. We use the constraint index developed by Whited and Wu 2004 and individual variables in their model as instrumental variables. DivPos seems to be the only variable that has a significant loading in Equation (2).

16. Consistent with the results of Nini et al. (2009), Kahan and Yarmack (2003) find that larger firms are more likely to have nonconvertible public debt with investment restrictions.

17. The importance of growth opportunities in the determining investment restriction covenants in public debt is also examined by Kahan and Yarmack 2003 using R\&D expenses to sales and Nash, Netter, and Poulson 2003 using the market to book ratio. Neither paper finds statistical significance on these growth variables.

18. Because all firms that issue public debt should be rated, we cannot test the effectiveness of Rated variable in the public debt sample. Instead, we test the effectiveness using an overall sample where we do not separate public and bank debt samples.

19. We use COMPUSTAT \#83 to identify whether there is a change in other bank debt or private placements. If there is an increase in \#83, we further require COMPUSTAT \#111 to be non-0 to ensure a debt issuance. 


\section{References}

Almeida, H., M. Campello, and M. Weisbach. 2004. The cash flow sensitivity of cash. Journal of Finance 59: 1777-1804.

Almeida, H., and M. Campello. 2007. Financial constraints, asset tangibility, and corporate investment. Review of Financial Studies 20: 1429-1460.

Alti, A. 2003. How sensitive is investment to cash flow when financing is frictionless? Journal of Finance 58: 707-722.

Barth, M., L. D. Hodder, and S.R. Stubben. 2008. Fair value accounting for liabilities and own credit risk. The Accounting Review 83: 629-664.

Bharath, S. T., J. Sunder, and S. V. Sunder. 2008. Accounting quality and debt contracting. The Accounting Review 83: 1-28.

Biddle, G., and G. Hilary. 2006. Accounting quality and firm-level capital investment. The Accounting Review 81: 963-982.

Biddle, G., G. Hilary, and R. Verdi. 2009. How does financial reporting quality improve investment efficiency? Working paper, MIT.

Billet, M., D. King, and D. Mauer. 2007. Growth opportunities and the choice of leverage, debt maturity, and covenants. Journal of Finance 62 (2): 627-729.

Bushman, R., J. Piotroski, and A. Smith. 2005. Capital allocation and timely accounting recognition of economic losses: international evidence. Working paper, University of Chicago.

Bushman, R., A. Smith, and F. Zhang. 2007. Investment-cash flow sensitivities are really investmentinvestment sensitivities. Working Paper, University of North Carolina.

Chava, S., P. Kumar and A. Warga. 2007. Managerial moral hazard and bond covenants. Working paper, University of Houston.

Chen, X., Q. Cheng, and K. Lo. 2006. Are analyst research and corporate disclosure complements of substitutes? Working paper, University of British Columbia.

Diamond, D. 1991. Monitoring and reputation: the choice between bank loans and privately placed debt. Journal of Political Economy 99: 689-721.

Denis, D. J., and V. T. Mihov. 2003. The choice among bank debt, non-bank private debt, and public debt: evidence from new corporate borrowings. Journal of Financial Economics 70: 3-28

Fazzari, S., R. G. Hubbard, and B. Petersen. 1988. Investment and finance reconsidered. Brookings Papers on Economic Activity 141-195.

Fazzari, S., R. G. Hubbard, and B. Petersen. 2000. Investment-cash flow sensitivities are useful: a comment on Kaplan and Zingales. The Quarterly Journal of Economics 115: 595-705.

Francis, J., K. Schipper, and L. Vincent. 2002. Earnings announcements and competing information. Journal of Accounting and Economics: 33: 313-342.

Francis, J., R. LaFond, P. Olsson, and K. Schipper, 2005. The market pricing of accruals quality. Journal of Accounting and Economics 39: 295-327. 
Holthausen, R., and R. Verrecchia. 1988. The effect of sequential information release on the variation of price changes in an intertemporal multi-asset market. Journal of Accounting Research 26: 82106.

James, C. 1987. Some evidence on the uniqueness of bank loans. Journal of Financial Economics 19: 217235.

Kahan, M., and D. Yermack. 2003. Investment opportunities and the design of debt securities. Journal of Law, Economics, and Organization 14 (1): 136-151.

Kaplan, S., and L. Zingales. 2000. Investment-cash flow sensitivities are not valid measures of financing constraints. The Quarterly Journal of Economics 115: 707-712.

Krishnaswami, S., P.A. Spindt, and V. Subramaniam. 1999. Information asymmetry, monitoring, and the placement structure of corporate debt. Journal of Financial Economics 51: 407-434.

Lee, L. 1978. Unionism and Wage Rates: a simultaneous equations model with qualitative and limited dependent variables. International Economic Review 19: 415-434.

Nash, R., J. Netter, and A. Poulson. 2003. Determinants of contractual relations between shareholders and bondholders: Investment opportunities and restrictive covenants. Journal of Corporate Finance 9: 201-232.

Nini, G., D. Smith, and A. Sufi. 2009. Creditor control rights and firm investment policy. Journal of Financial Economics, forthcoming.

Verdi, R. 2006. Financial reporting quality and investment efficiency. Working paper, MIT.

Whited, T. M., and G. Wu. 2004. Financial constraints risk. Working paper, University of Wisconsin.

Whittenberg-Moerman, R. W. 2008. The role of information asymmetry and financial reporting quality in debt trading: evidence from the secondary loan market. Journal of Accounting and Economics 46: 240-260.

Wysocki, P. 2005. Assessing earnings and accruals quality: U.S. and international evidence. Working paper, MIT.

Yu, J. 2007. Loan spreads and unexpected earnings: do banks know what analysts do not? Working paper, SMU. 
TABLE 1

Descriptive statistics (Means) by debt type for the period 2000-2005

\begin{tabular}{|c|c|c|c|c|}
\hline & Public Debt $^{++}$ & $\begin{array}{c}\text { Bank Debt } \\
\text { (t-stat for difference } \\
\text { between Bank and } \\
\text { Public Debt) }\end{array}$ & $\begin{array}{l}\text { Bank Debt without } \\
\text { Investment Covenant }\end{array}$ & $\begin{array}{l}\text { Bank Debt with Investment } \\
\text { Covenant (t-stat for } \\
\text { difference of bank debts } \\
\text { with and without covenants) }\end{array}$ \\
\hline $\mathrm{AQ}$ & 2.01 & $\begin{array}{c}2.00 \\
(0.37) \\
\end{array}$ & 2.005 & $\begin{array}{c}1.98 \\
(0.66) \\
\end{array}$ \\
\hline Investment & 0.05 & $\begin{array}{c}0.05 \\
(-0.05)\end{array}$ & 0.059 & $\begin{array}{c}0.05 \\
(7.04) * * *\end{array}$ \\
\hline $\mathrm{CFO}$ & 0.10 & $\begin{array}{c}0.10 \\
(-0.19)\end{array}$ & 0.105 & $\begin{array}{c}0.08 \\
(7.78)^{* * *}\end{array}$ \\
\hline TobinsQ & 1.62 & $\begin{array}{c}1.55 \\
(2.23)^{* *}\end{array}$ & 1.605 & $\begin{array}{c}1.44 \\
(5.63) * * *\end{array}$ \\
\hline Size & 8.84 & $\begin{array}{c}7.18 \\
(30.69)^{* * *}\end{array}$ & 7.541 & $\begin{array}{c}6.45 \\
(19.85)^{* * *}\end{array}$ \\
\hline Credit Rating & 3.17 & $\begin{array}{c}2.32 \\
(25.76) * * *\end{array}$ & 2.602 & $\begin{array}{c}1.76 \\
(26.87)^{* * *}\end{array}$ \\
\hline Leverage & 0.30 & $\begin{array}{c}0.29 \\
(1.04)\end{array}$ & 0.257 & $\begin{array}{c}0.36 \\
(-12.46)^{* * *}\end{array}$ \\
\hline Tangibility & 0.42 & $\begin{array}{c}0.43 \\
(-2.49) * * \\
\end{array}$ & 0.436 & $\begin{array}{c}0.42 \\
(3.76) * * * \\
\end{array}$ \\
\hline $\mathrm{ROE}$ & 0.13 & $\begin{array}{c}0.08 \\
(3.80)^{* * *}\end{array}$ & 0.109 & $\begin{array}{c}0.01 \\
(6.07)^{* * *}\end{array}$ \\
\hline$\Delta$ Cash & 0.01 & $\begin{array}{c}0.01 \\
(-1.28)\end{array}$ & 0.006 & $\begin{array}{c}0.01 \\
(-0.64)\end{array}$ \\
\hline Rated & N/A & $\begin{array}{c}0.61 \\
(\mathrm{~N} / \mathrm{A})\end{array}$ & 0.636 & $\begin{array}{c}0.55 \\
(5.09)^{* * * *}\end{array}$ \\
\hline FC Index & 0.53 & $\begin{array}{c}0.43 \\
(29.04) * * *\end{array}$ & 0.453 & $\begin{array}{c}0.38 \\
(21.89) * * *\end{array}$ \\
\hline DivPos & 0.80 & $\begin{array}{c}0.52 \\
(16.91)^{* * *}\end{array}$ & 0.638 & $\begin{array}{c}0.28 \\
(20.70)^{* * *}\end{array}$ \\
\hline $\begin{array}{c}\text { Number of } \\
\text { observations }\end{array}$ & 1,083 & 3,392 & 2,268 & 1,124 \\
\hline
\end{tabular}

++ Public Debt sample only includes firm-years for firms not listed in the SDC database as issuing a bank loan during the sample period

$* * *, * * *$ Significant at the $1 \%, 5 \%$, or $10 \%$ levels respectively.

\section{VARIABLE DEFINITIONS.}

Investment: the firm's total capital expenditures (COMPUSTAT \#128) divided by total average assets (COMPUSTAT \#6).

Bank: an indicator variable equal to one if the firm has outstanding bank debt financing, 0 otherwise.

Inv_Cov: an indicator variable equal to one when the bank debt contains a covenant restricting capital investment, 0 otherwise.

CFO: cash flow from operations (COMPUSTAT \#308) divided by average total assets (COMPUSTAT \#6).

AQ: $\quad$ the average of the rankings of the following 4 AQ measures.

AQ1: $\quad$ the quintile ranking of Adjusted $R$-squared from estimating a regression of total current accruals on cash flows from operations measured concurrently and with a one-period lead and one-period lag (Dechow and Dichev (2002)). When estimating the regression 


\begin{tabular}{|c|c|}
\hline$A Q 2:$ & $\begin{array}{l}\text { a measure of earnings persistence derived by regressing one period ahead earnings on } \\
\text { current earnings. When estimating the regression, we require at least eight years of } \\
\text { observations from the past } 10 \text { years, including the investment year. We use the quintile } \\
\text { ranking of the coefficient on current earnings as our measure of earnings persistence. }\end{array}$ \\
\hline AQ3: & $\begin{array}{l}\text { the quintile ranking of Adjusted } R \text {-squared from the earnings persistence model discussed } \\
\text { in AQ2. }\end{array}$ \\
\hline AQ4: & $\begin{array}{l}\text { the quintile ranking of Adjusted } R \text { squared from a regression of one year ahead cash flow } \\
\text { on current earnings. When estimating the regression we require at least eight years of } \\
\text { observations from the past } 10 \text { years, including the investment year. }\end{array}$ \\
\hline Tobins $Q$ : & $\begin{array}{l}\text { the book value of total assets (COMPUSTAT \#6) plus market value of equity } \\
\text { (COMPUSTAT \#199* COMPUSTAT \#25) minus book value of equity (COMPUSTAT } \\
\text { \#60) and deferred tax (COMPUSTAT \#74) divided by the book value of total assets. }\end{array}$ \\
\hline Size: & the log of total assets (COMPUSTAT \#6). \\
\hline Credit Rating: & $\begin{array}{l}\text { a categorical variable that ranges from } 1-4 \text {. For firms with rated debt the variable is } 1 \text { if } \\
\text { the rating is between } D \text { and } B+, 2 \text { if their rating is between } B B-\text { and } B B+, 3 \text { if their } \\
\text { rating is between } B B B-\text { and } B B B+, \text { and } 4 \text { if their rating is between } A \text {-and } A A A \text {. For firms } \\
\text { without rated debt, we follow Barth et al. } 2008 \text { to develop a credit rating that falls within } \\
\text { this } 1-4 \text { scale. }\end{array}$ \\
\hline Leverage: & $\begin{array}{l}\text { long-term debt (COMPUSTAT \#9) divided by the sum of long-term debt and market } \\
\text { value of equity (COMPUSTAT \#199* COMPUSTAT \#25). }\end{array}$ \\
\hline Tangibility: & $\begin{array}{l}\text { Almeida and Campello's (2007) estimate of asset tangibility: } 0.715^{*} \text { accounts receivable } \\
\text { (COMPUSTAT \#2) + 0.547* inventory (COMPUSTAT \#3) + 0.535*PPE (COMPUSTAT } \\
\# 8)+ \text { cash (COMPUSTAT \#1) divided by total assets (COMPUSTAT \#6). }\end{array}$ \\
\hline ROE: & $\begin{array}{l}\text { net income (COMPUSTAT \#172) divided by average shareholders' equity } \\
\text { (COMPUSTAT \#60). }\end{array}$ \\
\hline$\triangle$ Cash: & $\begin{array}{l}\text { the change in cash and cash equivalents (COMPUSTAT \#1) divided by total assets } \\
\text { (COMPUSTAT \#6). }\end{array}$ \\
\hline Rated: & an indicator variable that equals one for firms rated by the $S \& P$. \\
\hline FCIndex: & $-0.062 * T L T D+0.01 * D I V P O S+0.067 * S G+0.06 * S I Z E-0.043 * I S G+0.053 * C F$ \\
\hline TLTD: & $\begin{array}{l}\text { the firm's long-term debt (COMPUSTAT \#9) divided by total assets (COMPUSTAT } \\
\text { \#6). }\end{array}$ \\
\hline DivPos: & $\begin{array}{l}\text { an indicator that takes the value of one if the firm pays cash dividends (COMPUSTAT } \\
\# 21 \text { ). }\end{array}$ \\
\hline$S G:$ & the change in sales divided by lagged sales (COMPUSTAT \#12). \\
\hline$I S G$ : & the firm's three-digit industry sales growth. \\
\hline$C F:$ & $\begin{array}{l}\text { the ratio of cash flow, measured by earnings before extraordinary (COMPUSTAT \#123) } \\
\text { plus depreciation (COMPUSTAT \#14), to total assets. }\end{array}$ \\
\hline
\end{tabular}


TABLE 2

Determinants of the use of bank debt and the use of capital expenditure covenants

\begin{tabular}{|l|c|c|c|c|}
\hline \multirow{2}{*}{\multicolumn{1}{|c|}{ Variable }} & Coefficient & Z-stat & \multicolumn{2}{c|}{$\begin{array}{c}\text { Prediction of The Use of Capital } \\
\text { Expenditure Covenants }\end{array}$} \\
\hline Coefficient & Z-stat \\
\hline Intercept & 4.547 & $22.67^{* * *}$ & 2.002 & $3.39^{* * *}$ \\
\hline CF & -0.011 & -0.43 & 0.018 & 0.64 \\
\hline ROE & -0.227 & -0.51 & -0.615 & $-1.66^{*}$ \\
\hline TobinsQ & -0.049 & -0.74 & 0.035 & 0.69 \\
\hline Size & 0.026 & 0.77 & -0.028 & -0.65 \\
\hline Credit Rating & -0.196 & $-9.78^{* * *}$ & -0.166 & $-5.00^{* * *}$ \\
\hline Rated & -0.320 & $-7.80^{* * *}$ & -0.437 & $-9.41^{* * *}$ \\
\hline Leverage & -0.937 & $-9.84^{* * *}$ & 0.090 & 1.26 \\
\hline Tangibility & -0.633 & $-3.93^{* * *}$ & 0.327 & $2.05^{* *}$ \\
\hline DivPos & -0.854 & $-4.39^{* * *}$ & -0.855 & $-3.38^{* * *}$ \\
\hline Debt Amount & -0.100 & $-1.67^{*}$ & -0.244 & $-3.97^{* * *}$ \\
\hline Revolver & & & -0.016 & -0.56 \\
\hline \# of observations & 4,475 & & -0.401 & $-6.43^{* * *}$ \\
\hline Pseudo R-Squared & 0.2258 & & 3,345 & \\
\hline
\end{tabular}

***,**,* Significant at the $1 \%, 5 \%$, or $10 \%$ levels respectively.

VARIABLE DEFINITIONS.

$A Q: \quad$ the average of the rankings of $A Q 1, A Q 2, A Q 3$ and $A Q 4$.

CFO: $\quad$ cash flow from operations (COMPUSTAT \#308) divided by average total assets (COMPUSTAT \#6).

ROE: $\quad$ net income (COMPUSTAT \#172) divided by average shareholders' equity (COMPUSTAT \#60).

TobinsQ: $\quad$ the book value of total assets (COMPUSTAT \#6) plus market value of equity (COMPUSTAT \#199* COMPUSTAT \#25) minus book value of equity (COMPUSTAT \#60) and deferred tax (COMPUSTAT \#74) divided by the book value of total assets.

Size: $\quad$ the log of total assets (COMPUSTAT \#6).

Credit Rating: a categorical variable that ranges from 1-4. For firms with rated debt the variable is 1 if the rating is between $D$ and $B+, 2$ if their rating is between $B B-$ and $B B+, 3$ if their rating is between $B B B-$ and $B B B+$, and 4 if their rating is between $A-$ and $A A A$. For firms without rated debt, we follow Barth et al. 2008 to develop a credit rating that falls within this 1-4 scale.

Rated: $\quad$ an indicator variable that equals one for firms rated by the $S \& P$.

Leverage: long-term debt (COMPUSTAT \#9) divided by the sum of long-term debt and market value of equity (COMPUSTAT \#199* COMPUSTAT \#25).

Tangibility: $\quad$ Almeida and Campello's (2007) estimate of asset tangibility: $0.715 *$ accounts receivable (COMPUSTAT \#2) + 0.547* inventory (COMPUSTAT \#3) + 0.535*PPE (COMPUSTAT \#8) + cash (COMPUSTAT \#1) divided by total assets (COMPUSTAT \#6).

DivPos: $\quad$ an indicator that takes the value of one if the firm pays cash dividends (COMPUSTAT \#21).

Debt Amount: $\quad$ the natural log of the amount of the bank debt.

Revolver: $\quad$ an indicator variable that equals one if the loan is a revolver. 
TABLE 3

OLS and endogenous switching models of investment-cash flow sensitivities by type of debt for a sample of firms that issued debt between 2000 and 2005

\begin{tabular}{|c|c|c|c|c|}
\hline & \multicolumn{2}{|c|}{ OLS Model } & \multicolumn{2}{|c|}{$\begin{array}{c}\text { Endogenous Switching Model } \\
\text { (along with the endogeneity adjustment } \\
\text { of Inv_Cov)\# }\end{array}$} \\
\hline & Public Debt $^{++}$ & Bank Debt & Public Debt ${ }^{++}$ & Bank Debt \\
\hline Intercept & $\begin{array}{c}0.01 \\
(0.65) \\
\end{array}$ & $\begin{array}{c}0.01 \\
(0.18)\end{array}$ & $\begin{array}{c}0.01 \\
(0.03)\end{array}$ & $\begin{array}{c}-0.00 \\
(-0.23)\end{array}$ \\
\hline Inv_Cov & N/A & $\begin{array}{c}0.01 \\
(0.84) \\
\end{array}$ & N/A & $\begin{array}{c}0.01 \\
(1.23)\end{array}$ \\
\hline $\mathrm{AQ}$ & $\begin{array}{c}0.01 \\
(1.59) \\
\end{array}$ & $\begin{array}{c}0.01 \\
(0.81) \\
\end{array}$ & $\begin{array}{c}0.01 \\
(1.61)\end{array}$ & $\begin{array}{c}0.01 \\
(0.38) \\
\end{array}$ \\
\hline AQ *Inv_Cov & N/A & $\begin{array}{c}-0.00 \\
(-0.71)\end{array}$ & N/A & $\begin{array}{c}0.01 \\
(0.37)\end{array}$ \\
\hline $\mathrm{CFO}$ & $\begin{array}{c}0.41 \\
(10.32)^{* * *}\end{array}$ & $\begin{array}{c}0.38 \\
(13.95) * * *\end{array}$ & $\begin{array}{c}0.43 \\
(10.44)^{* * *} *\end{array}$ & $\begin{array}{c}0.38 \\
(14.57)^{* * * *}\end{array}$ \\
\hline CFO*Inv_Cov & N/A & $\begin{array}{c}-0.24 \\
(-4.77) * * *\end{array}$ & N/A & $\begin{array}{c}-0.32 \\
(-5.54) * * *\end{array}$ \\
\hline CFO*AQ & $\begin{array}{c}-0.07 \\
(-4.41) * * *\end{array}$ & $\begin{array}{c}-0.06 \\
(-5.41)^{* * *}\end{array}$ & $\begin{array}{c}-0.08 \\
(-4.47) * * *\end{array}$ & $\begin{array}{c}-0.05 \\
(-4.78) * * *\end{array}$ \\
\hline CFO*AQ* Inv_Cov & N/A & $\begin{array}{c}0.08 \\
(3.84)^{* * *}\end{array}$ & $\mathrm{~N} / \mathrm{A}$ & $\begin{array}{c}0.07 \\
(2.69)^{* * *}\end{array}$ \\
\hline $\mathrm{Q}$ & $\begin{array}{c}-0.01 \\
(-3.95) * * *\end{array}$ & $\begin{array}{c}0.01 \\
(1.06) \\
\end{array}$ & $\begin{array}{c}-0.01 \\
(-4.02)^{* * *}\end{array}$ & $\begin{array}{c}0.01 \\
(0.76)\end{array}$ \\
\hline Size & $\begin{array}{c}-0.01 \\
(-0.87) \\
\end{array}$ & $\begin{array}{c}-0.00 \\
(-0.53) \\
\end{array}$ & $\begin{array}{c}-0.00 \\
(-0.32) \\
\end{array}$ & $\begin{array}{c}0.01 \\
(1.10) \\
\end{array}$ \\
\hline Credit Rating & $\begin{array}{c}-0.01 \\
(-0.38)\end{array}$ & $\begin{array}{c}-0.00 \\
(-3.51) * * *\end{array}$ & $\begin{array}{l}-0.00 \\
(0.00)\end{array}$ & $\begin{array}{c}-0.03 \\
(-2.00)^{* *}\end{array}$ \\
\hline Leverage & $\begin{array}{c}-0.02 \\
(-1.93)^{*}\end{array}$ & $\begin{array}{c}-0.01 \\
(-2.52) * * \\
\end{array}$ & $\begin{array}{c}-0.02 \\
(-1.79)^{*} \\
\end{array}$ & $\begin{array}{c}-0.01 \\
(-1.20) \\
\end{array}$ \\
\hline Tangibility & $\begin{array}{c}0.05 \\
(5.73) * * *\end{array}$ & $\begin{array}{c}0.07 \\
(9.74)^{* * * *}\end{array}$ & $\begin{array}{c}0.06 \\
(5.74) * * *\end{array}$ & $\begin{array}{c}0.07 \\
(9.84) * * *\end{array}$ \\
\hline $\mathrm{ROE}$ & $\begin{array}{c}0.00 \\
(0.12) \\
\end{array}$ & $\begin{array}{c}-0.01 \\
(-1.28) \\
\end{array}$ & $\begin{array}{c}0.01 \\
(0.17) \\
\end{array}$ & $\begin{array}{c}-0.01 \\
(-1.01) \\
\end{array}$ \\
\hline $\begin{array}{l}\text { Industry and year } \\
\text { Fixed Effects }\end{array}$ & Yes & Yes & Yes & Yes \\
\hline \# of observations & 1,083 & 3,392 & 1,083 & 3,392 \\
\hline R-Squared & 0.4593 & 0.3935 & & \\
\hline \multicolumn{5}{|c|}{$\begin{array}{c}\text { Difference in coefficient on CFO between the two samples (Endogenous Switching Model): } \chi^{2}(1)=1.29, \mathrm{p}- \\
\text { value }=0.2570\end{array}$} \\
\hline & at on $\mathrm{CFO}^{*} \mathrm{AO}$ & $\begin{array}{l}\text { n the two sam } \\
\text { p-value }=0.2\end{array}$ & & (odel): $\chi^{2}(1)=$ \\
\hline
\end{tabular}

++ Public Debt sample only includes firm years for firms not listed in the SDC database as issuing a bank loan during the sample period

\# Inv_Cov in the endogenous switching model represents the predicted value (0 vs. 1) of Inv_Cov from Table 2 .

$* * *, * * *$ Significant at the $1 \%, 5 \%$, or $10 \%$ levels respectively.

\section{VARIABLE DEFINITIONS.}

Investment: the firm's total capital expenditures (COMPUSTAT \#128) divided by total average assets (COMPUSTAT \#6).

Bank: an indicator variable equal to one if the firm has outstanding bank debt financing, 0o otherwise. 
Inv_Cov: an indicator variable equal to one when the bank debt contains a covenant restricting capital investment, 0 otherwise.

CFO: cash flow from operations (COMPUSTAT \#308) divided by average total assets (COMPUSTAT \#6).

AQ: $\quad$ the average of the rankings of $A Q 1, A Q 2, A Q 3$, and $A Q 4$. .

Tobins: $\quad$ the book value of total assets (COMPUSTAT \#6) plus market value of equity (COMPUSTAT \#199 * COMPUSTAT \#25) minus book value of equity (COMPUSTAT \#60) and deferred tax (COMPUSTAT \#74) divided by the book value of total assets.

Size: $\quad$ the log of total assets (COMPUSTAT \#6).

Credit Rating: a categorical variable that ranges from 1-4. For firms with rated debt the variable is 1 if the rating is between $D$ and $B+, 2$ if their rating is between $B B$-and $B B+, 3$ if their rating is between $B B B$ - and $B B B+$, and 4 if their rating is between $A$-and $A A A$. For firms without rated debt, we follow Barth et al. 2008 to develop a credit rating that falls within this 1-4 scale.

Leverage: $\quad$ long-term debt (COMPUSTAT \#9) divided by the sum of long-term debt and market value of equity (COMPUSTAT \#199* COMPUSTAT \#25.)

Tangibility: $\quad$ Almeida and Campello's (2007) estimate of asset tangibility: 0.715* accounts receivable (COMPUSTAT \#2) + 0.547* inventory (COMPUSTAT \#3) + 0.535*PPE (COMPUSTAT \#8) + cash (COMPUSTAT \#1) divided by total assets (COMPUSTAT \#6).

ROE: $\quad$ net income (COMPUSTAT \#172) divided by average shareholders' equity (COMPUSTAT \#60). 
TABLE 4

OLS and endogenous switching models of investment-cash flow sensitivities by type of debt for a sample of financially constrained firms that issued debt between 2000 and 2005

\begin{tabular}{|c|c|c|c|c|}
\hline & \multicolumn{2}{|c|}{ OLS Model } & \multicolumn{2}{|c|}{$\begin{array}{c}\text { Endogenous Switching Model } \\
\text { (along with the endogeneity adjustment } \\
\text { for Inv_Cov)\# }\end{array}$} \\
\hline & Public Debt $^{++}$ & Bank Debt & Public Debt $^{++}$ & Bank Debt \\
\hline Intercept & $\begin{array}{l}0.082 \\
(0.85) \\
\end{array}$ & $\begin{array}{l}-0.024 \\
(-0.67)\end{array}$ & $\begin{array}{l}0.086 \\
(0.63) \\
\end{array}$ & $\begin{array}{l}-0.010 \\
(-0.30)\end{array}$ \\
\hline Inv_Cov & N/A & $\begin{array}{l}0.009 \\
(1.07) \\
\end{array}$ & N/A & $\begin{array}{l}0.005 \\
(0.60) \\
\end{array}$ \\
\hline $\mathrm{AQ}$ & $\begin{array}{l}0.009 \\
(1.10)\end{array}$ & $\begin{array}{l}0.003 \\
(1.34)\end{array}$ & $\begin{array}{l}0.009 \\
(1.20)\end{array}$ & $\begin{array}{l}0.001 \\
(0.40)\end{array}$ \\
\hline AQ *Inv_Cov & N/A & $\begin{array}{l}-0.004 \\
(-1.18)\end{array}$ & N/A & $\begin{array}{l}0.001 \\
(0.41)\end{array}$ \\
\hline $\mathrm{CFO}$ & $\begin{array}{c}0.718 \\
(6.55)^{* * *}\end{array}$ & $\begin{array}{c}0.398 \\
(9.76)^{* * *}\end{array}$ & $\begin{array}{c}0.720 \\
(7.09)^{* * *}\end{array}$ & $\begin{array}{c}0.395 \\
(10.39)^{* * *}\end{array}$ \\
\hline CFO*Inv_Cov & N/A & $\begin{array}{c}-0.257 \\
(-3.95)^{* * *}\end{array}$ & N/A & $\begin{array}{c}-0.334 \\
(-4.82)^{* * *}\end{array}$ \\
\hline CFO*AQ & $\begin{array}{c}-0.231 \\
(-4.90) * * *\end{array}$ & $\begin{array}{c}-0.087 \\
(-4.86) * * *\end{array}$ & $\begin{array}{c}-0.230 \\
(-5.28)^{* * *}\end{array}$ & $\begin{array}{c}-0.061 \\
(-3.70)^{* * *}\end{array}$ \\
\hline CFO*AQ* Inv_Cov & N/A & $\begin{array}{c}0.112 \\
(3.94)^{* * * *}\end{array}$ & N/A & $\begin{array}{c}0.076 \\
(2.47)^{* *}\end{array}$ \\
\hline Q & $\begin{array}{l}-0.000 \\
(-0.04) \\
\end{array}$ & $\begin{array}{c}0.005 \\
(3.14)^{* * *}\end{array}$ & $\begin{array}{l}-0.001 \\
(-0.05) \\
\end{array}$ & $\begin{array}{c}0.006 \\
(3.20)^{* * *}\end{array}$ \\
\hline Size & $\begin{array}{l}0.001 \\
(0.13)\end{array}$ & $\begin{array}{l}0.000 \\
(0.15)\end{array}$ & $\begin{array}{l}0.001 \\
(0.09)\end{array}$ & $\begin{array}{l}-0.000 \\
(-0.30)\end{array}$ \\
\hline Credit Rating & $\begin{array}{c}-0.012 \\
(-1.82)^{*}\end{array}$ & $\begin{array}{c}-0.005 \\
(-2.63) * * *\end{array}$ & $\begin{array}{c}-0.011 \\
(-1.76)^{*}\end{array}$ & $\begin{array}{c}-0.006 \\
(-2.95) * * *\end{array}$ \\
\hline Leverage & $\begin{array}{c}-0.075 \\
(-2.49)^{* *} \\
\end{array}$ & $\begin{array}{l}-0.006 \\
(-1.06) \\
\end{array}$ & $\begin{array}{c}-0.077 \\
(-2.37)^{* *} \\
\end{array}$ & $\begin{array}{l}0.000 \\
(0.01) \\
\end{array}$ \\
\hline Tangibility & $\begin{array}{l}-0.001 \\
(-0.02)\end{array}$ & $\begin{array}{c}0.081 \\
(7.46)^{* * * *}\end{array}$ & $\begin{array}{l}-0.003 \\
(-0.04)\end{array}$ & $\begin{array}{c}0.081 \\
(7.47)^{* * *}\end{array}$ \\
\hline ROE & $\begin{array}{l}0.008 \\
(0.86) \\
\end{array}$ & $\begin{array}{l}-0.002 \\
(-0.84) \\
\end{array}$ & $\begin{array}{l}0.008 \\
(0.88) \\
\end{array}$ & $\begin{array}{l}-0.001 \\
(-0.58) \\
\end{array}$ \\
\hline $\begin{array}{l}\text { Industry and year } \\
\text { Fixed Effects }\end{array}$ & Yes & Yes & Yes & Yes \\
\hline \# of observations & 153 & 1,808 & 153 & 1,808 \\
\hline R-Squared & 0.5511 & 0.3592 & & \\
\hline \multicolumn{5}{|c|}{$\begin{array}{c}\begin{array}{c}\text { Difference in coefficient on CFO between the two samples (Endogenous Switching Model): } \chi^{2}(1)=8.92, p- \\
\text { value }=0.0028\end{array}\end{array}$} \\
\hline & & p-value $=0$ & 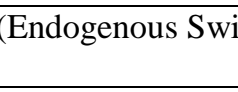 & (ael): $\chi(1)=$ \\
\hline
\end{tabular}

++ Public Debt sample only includes firm-years for firms not listed in the SDC database as issuing a bank loan during the sample period

\# Inv_Cov in the endogenous switching model represents the predicted value (0 vs. 1) of Inv_Cov from

Table 2.

$* * *, * * *$ Significant at the $1 \%, 5 \%$, or $10 \%$ levels respectively.

VARIABLE DEFINITIONS.

Investment: the firm's total capital expenditures (COMPUSTAT \#128) divided by total average assets (COMPUSTAT \#6). 
Bank: an indicator variable equal to one if the firm has outstanding bank debt financing, 0 otherwise.

Inv_Cov: an indicator variable equal to one when the bank debt contains a covenant restricting capital investment, 0 otherwise.

CFO: cash flow from operations (COMPUSTAT \#308) divided by average total assets (COMPUSTAT \#6).

AQ: $\quad$ the average of the rankings of $A Q 1, A Q 2, A Q 3$, and $A Q 4$.

Tobins: $\quad$ the book value of total assets (COMPUSTAT \#6) plus market value of equity (COMPUSTAT \#199* COMPUSTAT \#25) minus book value of equity (COMPUSTAT \#60) and deferred tax (COMPUSTAT \#74) divided by the book value of total assets.

Size: $\quad$ the log of total assets (COMPUSTAT \#6).

Credit Rating: a categorical variable that ranges from 1-4. For firms with rated debt the variable is 1 if the rating is between $D$ and $B+, 2$ if their rating is between $B B$ - and $B B+, 3$ if their rating is between $B B B$ - and $B B B+$, and 4 if their rating is between $A$-and $A A A$. For firms without rated debt, we follow Barth et al. 2008 to develop a credit rating that falls within this 1-4 scale.

Leverage: $\quad$ long-term debt (COMPUSTAT \#9) divided by the sum of long-term debt and market value of equity (COMPUSTAT \#199* COMPUSTAT \#25).

Tangibility: $\quad$ Almeida and Campello's (2007) estimate of asset tangibility: $0.715^{*}$ accounts receivable (COMPUSTAT \#2) + 0.547* inventory (COMPUSTAT \#3) + 0.535*PPE (COMPUSTAT \#8) + cash (COMPUSTAT \#1) divided by total assets (COMPUSTAT \#6).

ROE: net income (COMPUSTAT \#172) divided by average shareholders' equity (COMPUSTAT \#60). 
TABLE 5

Determinants of cash-cash flow sensitivities (OLS and endogenous switching models) by type of debt for a sample firms that issued debt between 2000 and 2005

\begin{tabular}{|c|c|c|c|c|}
\hline & \multicolumn{2}{|c|}{ OLS Model } & \multicolumn{2}{|c|}{ Endogenous Switching Model } \\
\hline & Public Debt $^{++}$ & Bank Debt & Public Debt $^{++}$ & Bank Debt \\
\hline Intercept & $\begin{array}{l}-0.021 \\
(-1.20)\end{array}$ & $\begin{array}{l}-0.000 \\
(-0.01)\end{array}$ & $\begin{array}{l}-0.009 \\
(-0.35)\end{array}$ & $\begin{array}{l}-0.029 \\
(-1.49)\end{array}$ \\
\hline $\mathrm{AQ}$ & $\begin{array}{c}0.006 \\
(2.71)^{* * *}\end{array}$ & $\begin{array}{l}0.001 \\
(0.52)\end{array}$ & $\begin{array}{c}0.006 \\
(2.74) * * *\end{array}$ & $\begin{array}{l}0.001 \\
(0.54)\end{array}$ \\
\hline $\mathrm{CFO}$ & $\begin{array}{c}0.247 \\
(5.84) * * *\end{array}$ & $\begin{array}{c}0.123 \\
(4.60)^{* * *}\end{array}$ & $\begin{array}{c}0.246 \\
(5.88)^{* * *} \\
\end{array}$ & $\begin{array}{c}0.122 \\
(4.56)^{* * *}\end{array}$ \\
\hline CFO*AQ & $\begin{array}{c}-0.071 \\
(-4.03) * * *\end{array}$ & $\begin{array}{l}-0.001 \\
(-0.07)\end{array}$ & $\begin{array}{c}-0.070 \\
(-4.07) * * *\end{array}$ & $\begin{array}{l}-0.002 \\
(-0.21) \\
\end{array}$ \\
\hline Q & $\begin{array}{l}-0.002 \\
(-1.30)\end{array}$ & $\begin{array}{l}-0.002 \\
(-1.38)\end{array}$ & $\begin{array}{l}-0.002 \\
(-1.22)\end{array}$ & $\begin{array}{l}-0.001 \\
(-1.14)\end{array}$ \\
\hline Size & $\begin{array}{c}0.002 \\
(1.99) * *\end{array}$ & $\begin{array}{c}0.002 \\
(2.99)^{* * * *}\end{array}$ & $\begin{array}{l}0.002 \\
(1.17)\end{array}$ & $\begin{array}{c}0.006 \\
(6.91)^{* * * *}\end{array}$ \\
\hline Credit Rating & $\begin{array}{l}-0.003 \\
(-1.33)\end{array}$ & $\begin{array}{c}-0.005 \\
(-3.44)^{* * *}\end{array}$ & $\begin{array}{l}-0.004 \\
(-1.49)\end{array}$ & $\begin{array}{l}-0.001 \\
(-0.86)\end{array}$ \\
\hline Leverage & $\begin{array}{l}0.008 \\
(0.91)\end{array}$ & $\begin{array}{l}-0.004 \\
(-0.86) \\
\end{array}$ & $\begin{array}{l}0.006 \\
(0.72) \\
\end{array}$ & $\begin{array}{l}0.004 \\
(0.81) \\
\end{array}$ \\
\hline Tangibility & $\begin{array}{c}-0.048 \\
(-5.07)^{* * *}\end{array}$ & $\begin{array}{c}-0.038 \\
(-4.86)^{* * *}\end{array}$ & $\begin{array}{c}-0.049 \\
(-5.16) * * *\end{array}$ & $\begin{array}{c}-0.028 \\
(-3.51)^{* * *}\end{array}$ \\
\hline ROE & $\begin{array}{l}0.006 \\
(1.64) \\
\end{array}$ & $\begin{array}{l}-0.000 \\
(-0.17) \\
\end{array}$ & $\begin{array}{l}0.006 \\
(1.58) \\
\end{array}$ & $\begin{array}{l}-0.000 \\
(-0.14) \\
\end{array}$ \\
\hline $\begin{array}{c}\text { Industry } \\
\text { Fixed Effects }\end{array}$ & Yes & Yes & Yes & Yes \\
\hline $\begin{array}{c}\text { Year } \\
\text { Fixed Effects }\end{array}$ & Yes & Yes & Yes & Yes \\
\hline \# of observations & 1,083 & 3,392 & & \\
\hline R-Squared & 0.0563 & 0.0446 & & \\
\hline \multicolumn{5}{|c|}{ 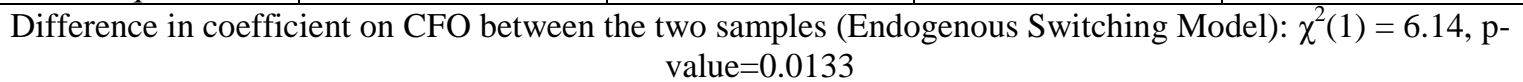 } \\
\hline Difference in coe & ent on $\mathrm{CFO}^{*} \mathrm{AQ}$ & $\begin{array}{l}\text { ne two sar } \\
5, \text { p-value }=0 .\end{array}$ & ndogenous Swi & Iodel): $\chi^{2}(1)$ \\
\hline
\end{tabular}

++ Public Debt sample only includes firm-years for firms not listed in the SDC database as issuing a bank loan during the sample period

$* * *, * * *$ Significant at the $1 \%, 5 \%$, or $10 \%$ levels respectively.

\section{VARIABLE DEFINITIONS.}

Investment: the firm's total capital expenditures (COMPUSTAT \#128) divided by total average assets (COMPUSTAT \#6).

Bank: an indicator variable equal to one if the firm has outstanding bank debt financing, 0 otherwise.

Inv_Cov: an indicator variable equal to one when the bank debt contains a covenant restricting capital investment, 0 otherwise.

CFO: cash flow from operations (COMPUSTAT \#308) divided by average total assets (COMPUSTAT \#6).

$A Q: \quad \quad \quad \quad \quad$ the average of the rankings of $A Q 1, A Q 2, A Q 3$, and $A Q 4$.

Tobins: $\quad$ the book value of total assets (COMPUSTAT \#6) plus market value of equity (COMPUSTAT \#199* COMPUSTAT \#25) minus book value of equity (COMPUSTAT \#60) and deferred tax (COMPUSTAT \#74) divided by the book value of total assets.

Size: the log of total assets (COMPUSTAT \#6). 
Credit Rating: a categorical variable that ranges from 1-4. For firms with rated debt the variable is 1 if the rating is between $D$ and $B+, 2$ if their rating is between $B B-$ and $B B+, 3$ if their rating is between $B B B$ - and $B B B+$, and 4 if their rating is between $A-$ and $A A A$. For firms without rated debt, we follow Barth et al. 2008 to develop a credit rating that falls within this 1-4 scale.

Leverage: $\quad$ long-term debt (COMPUSTAT \#9) divided by the sum of long-term debt and market value of equity (COMPUSTAT \#199* COMPUSTAT \#25).

Tangibility: $\quad$ Almeida and Campello's (2007) estimate of asset tangibility: $0.715 *$ accounts receivable (COMPUSTAT \#2) + 0.547* inventory (COMPUSTAT \#3) + 0.535*PPE (COMPUSTAT \#8) + cash (COMPUSTAT \#1) divided by total assets (COMPUSTAT \#6).

ROE: $\quad$ net income (COMPUSTAT \#172) divided by average shareholders' equity (COMPUSTAT \#60). 